\title{
Activity analysis: contributions to the innovation of projects for aircrafts cabins
}

\author{
Rossi, N. T.; Greghi, F. M.; Menegon, L. N. and Souza, G.B.J \\ Industrial Engineering Department, Universidade Federal de São Carlos (UFSCar) - Simucad Ergo\&Ação \\ Group (www.simucad.dep.ufscar.br.) Rodovia Washington Luiz, km 235 - São Carlos, SP, Brazil - 13.565-905.
}

\begin{abstract}
This article presents results obtained from some ergonomics intervention in the project for the conception of aircraft's cabins. The study's aim is to analyze the contribution of the method adopted in the passengers' activities analysis in reference situations, real-use situations in aircraft's cabins, applied to analyze typical activities performed by people in their own environment. Within this perspective, the study shows two analyses which highlight the use of electronic device. The first analysis has been registered through a shooting filming in a real commercial flight. In the second one, the use is developed within the domestic environment. The same method has been applied in both contexts and it is based on activity analysis. Starting with the filming activity, postures and actions analysis, self-confrontation interviews, action course reconstruction and elaboration of postures envelopes. The results point out that the developed method might be applied to different contexts, evincing different ways of space occupation to meet human personal needs while performing an activity, which can help us with the anticipation of the users' needs, as well as indicate some innovation possibilities.
\end{abstract}

Keywords: prospective ergonomics; design; activity analysis; user

\section{Introduction}

In this article we present discussions obtained from some ergonomics intervention in the project "Comfort and Design of Aircraft Cabins", which basically aims to investigate the relation between comfort and design within the innovation project for the conception of aircrafts cabins. The study has been developed through a partnership between Embraer and São Paulo Research (FAPESP), with the collaboration of the Universities: USP, UFSCar and UFSC. Besides these institutions, the National Agency of Civil Aviation (ANAC) contributed to the research offering logistical support that enabled the data collection.

Within this study an example for the application of the proposed method to the referred project has been presented, following the prospective ergonomics perspective, which suggests an analysis that transcends the classical reference situation to daily situations, aiming at the anticipation to the user's needs and the technological evolution on the development of products and innovative solutions.

\section{Passengers comfort and use analysis}

Comfort is a subject which has gained more relevance within the aviation industry due to the manufacturers and airline companies' necessities of differentiating themselves in a market that has become rather competitive each day [14]. The study of the real meaning of comfort suggests a construct subjectively defined by the personal nature, which is determined by the interaction of multiple factors; being those physical, physiological, and psychological, constituting a reaction to the environmental stimulus [7, 17, 20, 21].

Hence, the studies about the subject point out the difficulty in analyzing all the variables that interfere in the perception of comfort, in a way to create criteria for the application to innovation projects within the aeronautical industry. Previous studies have cited that the activity performed by the

Corresponding author: talita@dep.ufscar.br ; talitanrossi@gmail.com 
passenger interferes in the perception of comfort $[4$, $10,11,3]$.

However, within the aeronautical industry, it has been verified the existence of few studies that make use of such method in order to analyze comfort in the cabin, being most of them developed in a simulated environment $[2,18]$.

Taking into consideration the multiplicity of factors that have influenced comfort, the activity analysis presents itself as a pertinent approach, once according to Guérin, Laville, Daniellou, Duraffourg, Kerguelen (2001) the activity has an integrating function, organizing and structuring the components from a situation, including individual and environmental aspects. According to Béguin (2008) the activity is a source of situated creativity, which explores, interprets and reorganizes the data and the decisions throughout their development.

To Daniellou, Béguin (2007), along the ergonomics evolution focused on the activity analysis there have been developed a set of knowledge, methods and tools for the study of activities within real situations, especially, when performing labor activities.

Through the field studies made by ergonomics, it has been sought to reveal the difficulties and the different strategies developed by the users when dealing with use situations. The users' involvement and the activity analysis favor the knowledge of real practical use, as well as the insight of the users' needs and behaviors [13].

It is important to highlight that "the conception continues during the use", which means that the users not always make use of the products exactly as expected or predicted, and they modify them along the interaction. [1,13]. It is throughout the real activity, which always comprehends a part of seatback, that the individual changes the artifact, giving to it new meanings and ways of usage [6].

According to Béguin (2008) the artifacts functioning and the activity are not sufficiently considered in the conception, herewith, an incomplete model, sometimes an inaccurate one, from the user, from its activity and from the use situation, is incorporated to the product, in other words, the designer crystallizes his own created representation to the product.

In ergonomics, to take into consideration the use situations and the users' participation in the products' development, two perspectives can be considered: conception and prospection. The approach of the ergonomics of conception, according to the model proposed by Garrigou, Thibault, Jackson, Mascia (2001) and adapted by Menegon (2005), has been based upon the analysis of the activity in classical reference situations, aiming to identify the elements within the products variability, the action put into practice by the users to face such variability, and the strategies to reduce the constraints concerning the real. From this point of view, it has been possible to reconstruct the activity under the shape of scenarios that will be used in situation of simulation for the future activity. So, it has been praised a dialogical model of conception, in which, logics and positions from heterogeneous actors are put within the same situation [1].

The prospective ergonomics approach, to Robert, Brangier (2009) can be defined as the part of ergonomics that attempts to anticipate human needs and activities, in order to create new artifacts that will be useful and provide positive user experience. To anticipate the human needs and activities it is necessary to keep a close contact with the people in their environment, in order to, from the observations and interviews, collect information from different aspects of their everyday lives.

The proximity in relation to the user's daily life is also relevant since the use is determined by social aspects. The products' appropriation by the user is influenced by mechanisms of social acceptance, which work as potential tools for the diffusion of products and practices, and can give origin to innovation solutions [13].

Either the conception ergonomics, or the prospective ergonomics, are for the development of new products, however, traditionally, the analysis of use situations has been based on an analysis of existing products, within a given reference situation, and on theoretical concepts (for example, affordance, usability) that help the designers define products that offer an even more positive experience to the user [13]. On the other hand, the prospective perspective, as far as we can see, differentiates itself by praising the extent of the analysis context, seeking new innovation possibilities.

Herewith, it has been highlighted the importance of extending the analysis to future situations and not restricting the ergonomics intervention to the existing projects, transcending the focus from the reference situations to the everyday ones, enabling the identification from a wider spectrum of possible uses and the investigation of new uses trends $[15,16]$.

At last, it is important to highlight that taking into consideration the results obtained from the study of 
comfort in aircraft's cabins, which corroborate other researches [2, 7, 19], it has been verified that the space in the cabin is a factor that restricts the activity, so, analyzing, within different contexts, the activities typically developed by the passengers during the flight, will extend the understanding and the anticipation people's needs in use, complementing the collected data and enabling the creation of new ways of thinking about the aircrafts cabins, having as innovation sources the user and the context of everyday life.

Thus, this study aims to analyze the contribution of the method adopted in the passengers' activities analysis in reference situations, real-use situations in aircraft's cabins, applied to analyze typical activities performed by people in their own environment. It is expected that the comparison between the results obtained in both analyses may bring contributions to innovations in aircraft cabins.

\section{Method}

The method applied to this study has been developed in the Project "Comfort and Design of Aircraft Cabins", previously cited, from a literature review about comfort and more specifically, comfort in aircraft cabins, interviews with experts from the aeronautical sector, and observations made during real flights.

To this study the same method has been applied to a preliminary research/survey under the focus of the prospective ergonomics.

\subsection{Stages from the proposed method.}

The method once elaborated for the use analysis has been based on the activity analysis and on the reconstruction of the course action, consisting of the following stages:

a) User's shooting filming. There have been made footage with the passengers' agreement during the embarking, cruising and the disembarking. Measurements of the seat dimensions and the space available for the passenger had also been made, by using a measuring protocol and a Bosh DLE 70 Professional laser distance measurer.

b) Data analysis, application of the Cronoanalysis Ilios Pose 2.0 Software, created by the Group Ergo\&Ação from UFSCar. Such software enables to analyze the videos and identify the postures adopted by the users along the action course, as well as the used equipment and artifacts, the difficulties and successes, and atypical situations. With this analysis it is possible to identify the action course of each passenger, as well as obtain quantitative analyses from the data collected during the filmings;

c) Restitution and validation of the data together with the users and return of the collected data for the users, making use of the self-confrontation method, which has constituted in sending the video to the passenger and a later discussion, over the phone or by internet chat, about the observed events and activities. Such stage has enabled deep analysis of the data collected so far, as well as the identification of the main constraints and variables related to discomfort.

d) Reconstruction of the action courses, using the Ramsis v3.8.28 Software; ${ }^{1}$

e) Creation of Postures Envelopes, using the Ramsis v3.8.28 Software; ${ }^{1}$

f) Calculation of the occupied area, using Rapdform XOR3 Software;

\subsection{Sample characterization.}

\section{Analysis in reference situation: real commercial flights}

Use analyses have been made in 40 domestic commercial flight stretches, in which 44 direct observations by filming and 4 self-confrontation interviews have been registered. In this study the analysis of a passenger during a real flight from the city of Marabá to Brasília will be presented. The flight's duration was 1 hour and 30 minutes.

\begin{abstract}
Analysis within diversified contexts from the everyday life.

A use analysis within a domestic context has been made through filming and self-confrontation interview, making use of the same method adopted during real flights. No measuring has been performed in the analyzed environment. It has been sought to film the use of electronic device in a distinct context from the flight situation, aiming to compare, for instance, the difficulties and strategies adopted in different contexts of use.
\end{abstract}

\footnotetext{
1 Contributions of Silva, A. F. R., Iwasaki, C. E. H., Campos, D. C. Q., Ferreira, J. A. L. from Group Ergo\&Ação/UFSCar
} 


\section{Results}

\subsection{Reference situation analysis: commercial flight.}

The passenger who has been filmed was male, aged between 51 and 60 years old, 1,68 tall and weighed $66 \mathrm{~kg}$. The main propose of his trips is business.
From the data analysis, the passenger's action course has been reconstructed (Graphic 1). In this graphic it is possible to verify: the activities performed by the passenger during the cruising, the performance sequence, the time he remained at each activity and the main adopted postures, described in Table 2. The analysis has been taking approximately for one hour and five minutes.

Graphic 1

Action Course along the flight (Cruising)

\begin{tabular}{|c|c|}
\hline \multicolumn{2}{|c|}{ ACTION COURSE ALONG THE CRUISING } \\
\hline Resting and sleeping & 00:05:51 \\
\hline Making one self comfortable & 00:00:14 \\
\hline Making use of electronic devices & 00:51:44 \\
\hline Observing the environment & 00:00:37 \\
\hline Interacting with other passengers & 00:02:37 \\
\hline Feeding & 00:03:36 \\
\hline Placing objects in the seat bag & 00:00:05 \\
\hline Analys is along the cruising & 01:04:44 \\
\hline
\end{tabular}

From Graphic 1, it has been verified that during the cruising the passengers has performed such activities: making him-herself comfortable (finding seat, organizing the hand luggage) resting and sleeping, feeding, interacting with other passengers, checking the environment and making use of electronic device.

During the cruising, the passenger remained the greatest part of the time $(00: 51: 44)$ performing the activity of making use of electronic device, in this case, the laptop. Through the restitution and validation process it has been verified that the passenger reported more difficulties in performing such activity. The mentioned difficulties were related to the available space and the resources offered by the aircraft (table, adapter for recharging the device's batteries). The main difficulties, facilities, and strategies mentioned by the passengers, in performing each activity are displayed in Table 1.
In relation to the postures adopted throughout the filming period (01:04:44) the passenger has shown 54 distinct postures, changing its position in several moments. Table 2 presents the main adopted postures, as well as the activities performed. The time the passenger remained at the presented postures is $00: 44: 38$, which corresponds to $80 \%$ of the total filming. The colors of each posture are correlated to the activities in Graphic 1.

From the data at Table 2, it has been verified that the passenger cannot change the arms position in order to use the electronic device.

It is possible to verify that the difficulties reported by the passenger related to space are portrayed by the adopted postures. According to the passenger, the fact of not having enough space to move his arms has hindered variations with the upper limbs. From the data at Table 1, it has been verified that the passenger has shown difficulties in changing the arms position while making use of the electronic device. 
Table 1

Main difficulties, easiness and strategies mentioned by the passenger in the self-confrontation interview

\begin{tabular}{|c|c|c|c|}
\hline & DIFFICULTIES & EASINESS & STRATEGIES \\
\hline $\begin{array}{l}\text { Embarking and } \\
\text { Debarking }\end{array}$ & - Takes too long & & \\
\hline $\begin{array}{l}\text { Organizing the hand } \\
\text { luggage }\end{array}$ & $\begin{array}{l}\text { - Had no difficulties in } \\
\text { accessing the luggage Bin } \\
\text { - Lack of space }\end{array}$ & & $\begin{array}{l}\text { - Carrying the backpack on } \\
\text { the lap }\end{array}$ \\
\hline Using a laptop & $\begin{array}{l}\text { The passenger reported that } \\
\text { is used to traveling on } \\
\text { business. } \\
\text { - The fact of not being able } \\
\text { to use the mouse } \\
\text { - Restricted space, since it } \\
\text { is not possible to feed } \\
\text { oneself and use the laptop } \\
\text { at the same time }\end{array}$ & $\begin{array}{l}\text { Front-back regulation for } \\
\text { the laptop to stay closer, } \\
\text { what makes visualization } \\
\text { easier } \\
\text { - Adapters in the aircraft to } \\
\text { recharge the laptop } \\
\text { battery }\end{array}$ & \\
\hline Resting and Sleeping & $\begin{array}{l}\text { - Seat width } \\
\text { - Restricted space }\end{array}$ & $\begin{array}{l}\text { - No problems with the } \\
\text { space for the legs } \\
\text { - Support for feet/legs with } \\
\text { regulation (there was } \\
\text { none in the aircraft) }\end{array}$ & $\begin{array}{l}\text { - Postures changes while } \\
\text { looking for the "best } \\
\text { position" }\end{array}$ \\
\hline Feeding & $\begin{array}{l}\text { - Feeding and working at } \\
\text { the same time } \\
\text { - Dropping food and } \\
\text { beverages on the laptop }\end{array}$ & & $\begin{array}{l}\text { - Posture change to feed } \\
\text { oneself } \\
\text { - Stop using the laptop } \\
\text { placing it on the next seat }\end{array}$ \\
\hline $\begin{array}{l}\text { Interacting with other } \\
\text { passengers }\end{array}$ & - Lack of space & & $\begin{array}{l}\text { - Looks for "a better } \\
\text { position" in order to talk }\end{array}$ \\
\hline
\end{tabular}

Table 2

Main postures adopted during the cruising

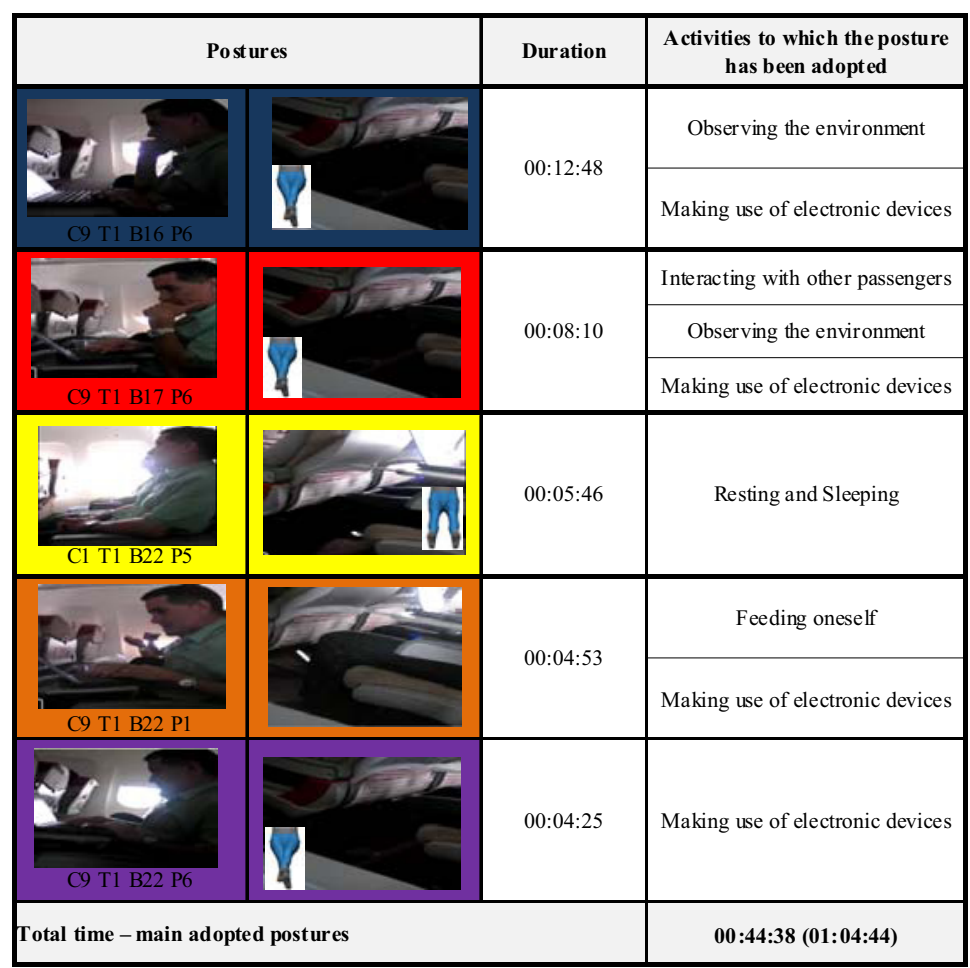


From the reconstruction of the action course it has been possible to elaborate envelopes of posture in order to analyze the areas taken by the passengers during the performance of in-flight activities. As shown in Figures 1 and 2.

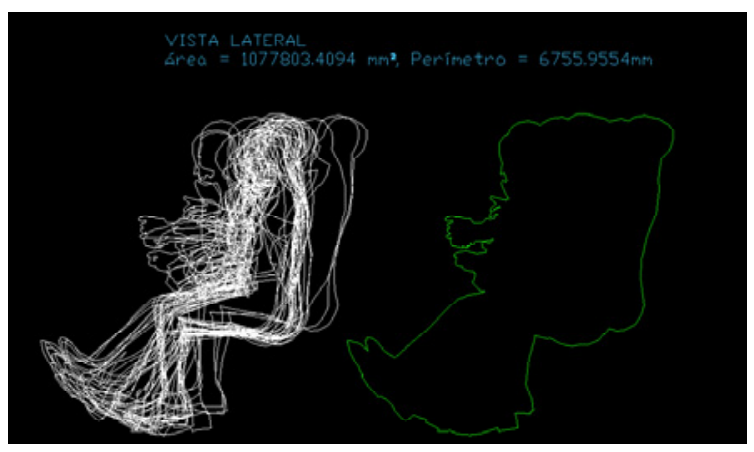

Figure 1

Envelope of posture - Passenger (Sideline view)

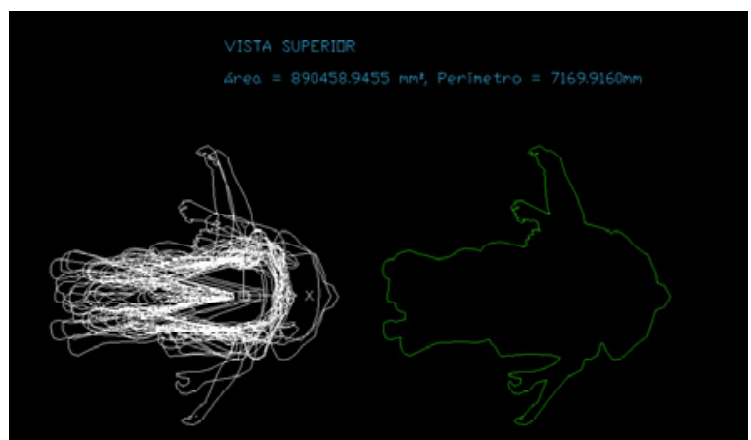

Figure 2

Envelope of posture - Passenger (Upper View)

Comparing the envelopes of postures with the space available in the seat, according to the dimensions shown at Table 3 , it is observed that the area taken by the passenger during the whole cruising period $\left(1077803 \mathrm{~mm}^{2}\right.$ side e $890458 \mathrm{~mm}^{2}$ upper) while performing the activity of making use of electronic device is larger than the useful space available in the seat for this flight $(776 \mathrm{~mm})$. The fact that there is no other person next to him has made possible for the passenger to exceed his seat's space.

Table 3

Seats Dimension/ passenger's space in the observed flight

\begin{tabular}{|lc|}
\hline \multicolumn{2}{|c|}{ Seat Dimension/ space (mm) } \\
\hline Cushioning width & 518 \\
\hline Cushioning height & 764 \\
\hline Cushioning length & 431 \\
\hline Seat width & 500 \\
\hline Distance between armrests & 485 \\
\hline Seat height from the floor & 425 \\
\hline Pitch & 74 \\
\hline Useful space & 776 \\
\hline Distance from the seat cushioning to the bin & 481 \\
\hline Space between the arms (aisle) & 485 \\
\hline Distance from the floor to the bin & 1599 \\
\hline
\end{tabular}

\subsection{Analysis in the everyday situation: domestic use.}

The filmed user within the domestic context, was a female one, aged between 18 and 30, her stature was 1,75 and she weighed $69 \mathrm{~kg}$. According to the user, the use of electronic devices is restricted to laptop and iPod, for academic, leisure and social interaction purposes.

The shooting filming lasted about 30 minutes and has been developed in the domestic environment, in a TV room. The user remained the entire time seated in the coach, keeping her laptop on the right arm support. From the data analysis the action course has been reconstructed (Graphic 2).

Graphic 2

Action Course: analysis in the everyday situation (domestic environment)

\begin{tabular}{|c|c|}
\hline ACTION COURSE IN THE DOMESTIC USE & Time \\
\hline Making use of electronic device & $00: 28: 57$ \\
\hline Interacting with other people & 00:00:08 \\
\hline Making use of electronic device and watching TV & 00:00:16 \\
\hline Making use of electronic device and interacting with others & 00:00:46 \\
\hline Making oneself comfortable & 00:00:04 \\
\hline Watching a video and interacting & 00:00:04 \\
\hline Making use of electronic device and observing the environment & 00:00:02 \\
\hline Total Analysis & 00:30:17 \\
\hline
\end{tabular}


The user has reported not having any difficulties in performing the activity.

Concerning the adopted postures, rather 52 different postures have been identified, which indicates, about two different postures for each minute of shooting filming. Table 4 displays the postures in which the passenger remained for longer periods, as well as the respective activities performed. The time the user remained in such main postures has been about 17 minutes, $52 \%$ of the analyzed time. So, as in the previous situation, the colors for each posture are correlated to the activities and the moment they happen throughout the action course (Graphic 2).

Table 4

Main postures adopted during the domestic environment use

\begin{tabular}{|c|c|c|}
\hline Postures & Duration & $\begin{array}{l}\text { Activities to which the posture } \\
\text { has been adopted }\end{array}$ \\
\hline C9 T23 B? P & $00: 05: 53$ & Making use of electronic devices \\
\hline C12 T20 B & $00: 03: 58$ & Making use of electronic devices \\
\hline C12 T23 B? & 00:03:51 & Making use of electronic devices \\
\hline C9 T22 B? & $00: 02: 14$ & Making use of electronic devices \\
\hline C9 T23 B? P. & $00: 01: 37$ & Making use of electronic devices \\
\hline Total time - main & postures & $00: 17: 33(00: 30: 17)$ \\
\hline
\end{tabular}

From the action course reconstruction, envelopes of every adopted posture while performing the analyzed activity have been elaborated and displayed in Figures 3 and 4.

From the comparison between both analyses it has been verified that the space available for the user determines the body's position while performing each activity. During the use within the domestic environment the participant had more frequent posture changes, which can be related to the fact of the environment being less restrictive about the posture flexibilization, either due to the space availability or to the fact of not being under rules and regulamentations that is the case of the analysis performed in the flight.

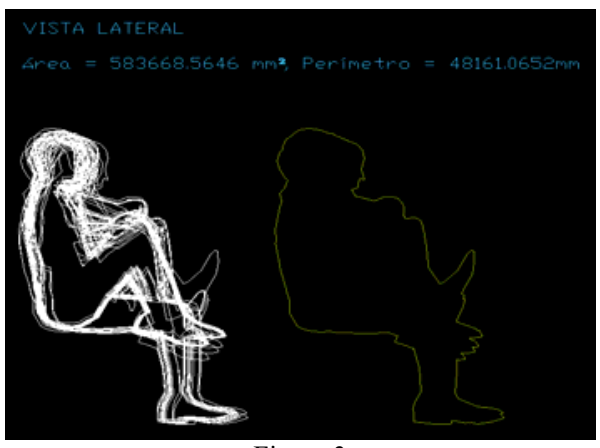

Figure 3

Envelope of Posture: Domestic User (Sideline View)

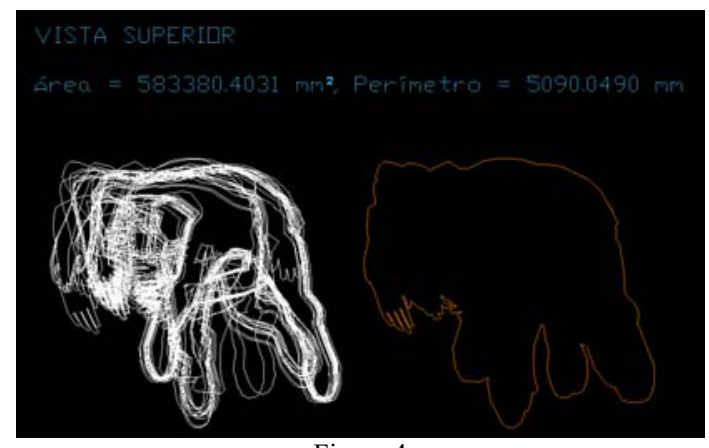

Figure 4

Envelope of Posture: Domestic User (Upper View)

Furthermore, it has been observed that in the second analysis, the user has taken a bigger horizontal space, keeping her back, for example, sidelong inclined, what has not happened in Analysis 1 , in which there was a restriction determined by the seat width. In the analysis 1 the user (passenger) showed difficulties in varying the upper limbs position, however, for being shorter, he was able to change the lower limbs position, stretching the legs during many moments, under the seat in front of him, as an attempt to change his position according to the available space.

Concerning the noticed difficulties, it has been verified that, differently from what has been pointed in the airline transportation, in the domestic environment, difficulties have not been reported in performing the activity, which may be related to the possibility of choosing the space in which someone wants to perform the activity. In the aircraft cabin, the space is predetermined and there are few possibilities of regulation, aiming the adjustment to the personal needs. 


\section{Conclusion}

From the analysis in the reference situation, real commercial flights, it has been verified that the main contributions from the method have been the identification of the in-flight activities performed, of the constraints experienced by the passengers, and the strategies adopted by those in order to perform what they may wish. Moreover, the elaboration of the envelopes of posture and the calculation of the area show themselves as important tools for conception projects within the aeronautical industry once they enable analyses in relation to the space in the cabin.

Concerning the method application to diversified contexts of everyday life, for example, in the domestic environment, it has been observed that it enables the identification of different ways to take advantage of the available space, showing different regulations used by the user while performing each activity.

The analysis confrontation has pointed how much the activity performanced has been influenced by the space available for the user, determining the adopted postures and the possibilities of regulation. Such analyses have pointed the importance of implementing some changes to the cabin environment which increase the possibility of regulation and are relevant to the conception Project, since the space is an essential factor of competitiveness for the companies, and the fact of being restricted in the economy class, the target of this study, makes it important to study ways of increasing the passengers' regulation in such environments.

Therefore, it has been concluded that the method developed for analyses in real flight situations can be applied to analyses in different contexts. The comparison between the analyses has enabled to verify the restrictions imposed by the space, and the users' main sources of difficulties. Such data make possible to identify the users' future needs, working as a source of innovation. Nevertheless, it is an initial study and it has made necessary the expansion of the collection and the data analysis for diversified situations. Taking into consideration having more consistent data and analyses, it can be possible to conceive specific solutions to aircraft cabins.

\section{References}

[1] Béguin, P. (2008). Argumentos para uma abordagem dialógica da inovação. Laboreal, 4(2), 72-82.

[2] Bertgelot, S. \& Bastien, J. M. C. (2009, juin). Apport de l'ergonomie au design de produit: application au siège d'avion. Conférence Ergodesign Forum, Lyon, França.
[3] Branton, P. (1969). Behaviour, Body Mechanics and Discomfort. Ergonomics, 12(2), 1969, 316-327.

[4] Bronkhorst, R. E., Krause, F. (2005). Designing comfortable passenger seats. In: VINK, P. Comfort and design: principles and good practice. 155-167. Florida: CRC Press.

[5] Daniellou, F., Béguin, P. (2007). Metodologia da ação ergonômica: abordagens do trabalho real, in Falzon, P., ed., Ergonomia. São Paulo: Editora Blucher, 281-301.

[6] Dejours, C.: O fator humano. Rio de Janeiro: Editora da FGV; 1997.

[7] Dumur, E., Barnard, Y., Boy, G. (2004). Designing for comfort. In: Waard, D. de; Brokhuis K. A.; Weikert, C. M. eds., Human Factors in Design, Maastricht, the Netherlands, Shaker Publishing, 111-127.

[8] Garrigou, A., Thibault, J.F., Jackson, M., Mascia, F. (2001) Contributions et démarche de l'ergonomie dans les processus de conception. Pistes, 3(2), Octobre, 1-18.

[9] Guérin, F., Laville, A., Daniellou, F., Duraffourg, J., Kerguelen, A. (2001). Trabalho, tarefa e atividade, in: Compreender o trabalho para transformá-lo. São Paulo, SP: Edgard Blücher.

[10]Han, S.H, Jung, E. S., Jung, M., Kwahk, J., Park, S. (1998). Psychophysical methods and passenger preferences of interior designs. Applied Ergonomics, 29 (6), 499-506.

[11] Jacobson, D. I., Martinez, A. J. (1974). The comfort and satisfaction of air travellers- basis for a descriptive model. Human Factors, 16(1), 46-55.

[12] Menegon, N. L. (2005). Referencial para o Projeto da Técnica. São Carlos: Departamento de Engenharia de Produção, Apostila de Engenharia do Trabalho 2, 144p.

[13]Nelson, J., Buisine, S., Aoussat, A. (2009). Assisting designers in the anticipation of future product use. AIJSTPME, 2(3), 25-39.

[14]Quehl, J. (2001). Comfort studies on aircraft interior sound and vibration. Ph.D. Dissertation, University of Oldenurg zur Erlangung des Grades.

[15]Robert, J.M., Brangier, E. (2009). What is prospective ergonomics? A reflection and a position on the future or ergonomics, in: Karsh, B.T., ed., Ergonomics and Health Aspects, HCII, LNCS 5624, 162-169.

[16] Robert, J.M. , Brangier, E. (2010) Manifeste pour l'ergonomie prospective : anticiper de futures activités humaines en vue de concevoir de nouveaux artéfacts. IMH 2010, September 2023, Luxembourg.

[17] Slater, K. Human comfort; Springfield, Illinois, U.S.A.; Charles C. Thomas, 1985. 249p.

[18] Tan, C. F., Member IAENG, Chen, W., Kimman, F., Rauterberg, G. W. M. (2009, july). Sleeping Posture Analysis of Economy Class Aircraft Seat. Proceedings of the World Congress on Engineering, 1, 1-3, London: U.K.

[19] Vink, P., Looze, M. P., Huijt-Evers, P., Kamp, I., Blok, M.(2000). Aircraft interior comfort experience. Delft University of Technology/ Faculty Industrial Design Engineering.

[20] Vink, P., Overbeeke, C.J., Desmet, P.M.A. (2005). Comfort experience, in: Vink, P. Comfort and design principles and good practice. Boca Raton, FL: CRC Press, 1-12.

[21]Zhang, L. (1996). Identifying Factors of Comfort and Discomfort in Sitting. Human Factors, 38(3), 377-389. 